\title{
COSPLAY SEBAGAI AJANG MENDAPATKAN PENGAKUAN MASYARAKAT (Analisis Politik Identitas Cosplayer di Dunia Virtual)
}

\author{
Khairul Syafuddin \\ Kajian Budaya dan Media, Sekolah Pascasarjana, Universitas Gadjah Mada \\ Korespondensi: Jalan Teknik Utara, Pogung, Yogyakarta \\ Surel: khairul.syafuddin@mail.ugm.ac.id
}

INFO ARTIKEL

\section{Sejarah Artikel:}

Diterima: 30/06/2020

Direvisi: 21/08/2020

Dipublikasikan: 30/09/2020

e-ISSN: 2721-0995

p-ISSN: 2721-9046

Kata Kunci:

cosplay, crossdresser, politik identitas, Youtube

Keywords:

cosplay, crossdresser, identity politics, Youtube

\section{A B STRAK}

Cosplay sebagai Ajang Mendapatkan Pengakuan Masyarakat (Analisis Politik Identitas Cosplayer di Dunia Virtual). Cosplay telah menjadi budaya populer yang melekat dalam kehidupan masyarakat Indonesia, khususnya bagi kalangan muda. Politik identitas yang muncul di sini memiliki keterkaitan dengan isu gender di masyarakat. Hal ini juga semakin diperluas dengan hadirnya Youtube dan Instagram untuk menunjukkan eksistensi dirinya. Penelitian ini menggunakan metode deskriptif kualitatif. Peneliti mengambil sampel berupa empat video dari Youtube serta postingan dari Instagram guna memperkuat pembahasan tentang fenomena crossdresser. Hasil dari penelitian ini melihat bahwa meski seorang individu telah melakukan crossdresser, mereka tidak seutuhnya berperan sebagai perempuan. Mereka masih menunjukkan dirinya sebagai laki-laki, terutama ketika menampilkan dirinya di Youtube. Selain itu, ketika secara pribadi menampilkan dirinya di Instagram, seorang cosplayer lebih dapat mengekspresikan dirinya dengan leluasa.

\section{ABSTRACT}

Cosplay as an Event to Get Public Recognition (Political Analysis of Cosplayers Identity in Virtual World. Cosplay has become a popular culture that is part of Indonesian society, especially for young people. The identity politics here are related to gender issues in society. This has also been further expanded by the presence of Youtube and Instagram to show their existence. This study used descriptive qualitative method. Researcher took samples in the form of four videos from Youtube and posts from Instagram to strengthen the discussion about the crossdresser phenomenon. The results of this study show that even though an individual has cross-dressed, they are not completely female. They still show themselves as men, especially when presenting themselves on Youtube. In addition, when personally presenting herself on Instagram, a cosplayer is more able to express herself more freely. 


\section{PENDAHULUAN}

Perkembangan budaya populer di Indonesia kini semakin marak. Salah satu budaya populer yang terus berkembang pesat hingga saat ini adalah cosplay. Ellyssa Kroski menjelaskan bahwa cosplay biasanya dilakukan ketika ada event atau konvensi anime (Ardhani, Wulan, \& Malau, 2017). Event tersebut kini tersebar di seluruh negara dan telah menjadi budaya populer, salah satunya di Indonesia. Di Indonesia sendiri, cosplay sudah tersebar cukup luas dan digemari berbagai kalangan. Budaya populer ini meski terlihat hanya digemari oleh anak-anak muda. Namun, pada kenyataannya banyak pula orang dewasa yang juga terjun dalam dunia ini sehingga cosplay dapat dikatakan sebagai budaya populer yang juga mampu menggapai seluruh masyarakat dari berbagai golongan.

Cosplay merupakan budaya populer yang berkembang dari budaya Jepang, yang muncul karena adanya rasa suka para fans terhadap karya manga, anime, hingga video games. Rasa suka tersebut kemudian mereka curahkan dengan menggunakan kostum para karakter yang disukai, dan hal itu diwadahi dalam event cosplay. Terlebih, hal ini kemudian semakin menyebar dengan adanya bantuan teknologi informasi yang membuat berbagai kalangan menikmati hasil dari produk budaya populer ini. Terkait dengan para pelaku cosplay, mereka tidak hanya dapat dilihat berdasarkan rasa suka mereka terhadap karakter dalam suatu manga, anime, atau video games. Namun lebih kompleks lagi, bagaimana mereka memilih karakter untuk ditiru juga terkait dengan identitas apa yang ingin mereka tampilkan. Hal ini dikarenakan setiap karakter tersebut memiliki karakter yang berbeda-beda sehingga ketika seorang pelaku cosplay telah memilih karakter yang mereka ingin tampilkan, hal itu secara tidak langsung diharapkan dapat mewakili representasi dari identitas mereka.

Berdasarkan latar belakang tersebut, dapat dilihat bahwa yang dilakukan para cosplayer baik dalam event cosplay maupun dalam dunia virtual merupakan bentuk dari politik identitas, yakni mereka juga ingin menunjukkan dan eksis sesuai dengan identitas yang diinginkan. Selain itu, dalam masyarakat yang memandang cara berpakaian sudah mapan sesuai dengan etika yang berlaku, maka ketika pakaian cosplay dipakai di tengah masyarakat, akan menjadikan para cosplayer sebagai pihak yang aneh dan menjadikannya sebagai pihak yang tersubordinat sehingga event cosplay dan dunia virtual menjadi bentuk dari cara mereka melakukan perlawanan terhadap kemapanan berpakaian serta memperoleh pengakuan (recognition) dari identitas yang ingin ditampilkan.

Penelitian ini bertujuan untuk menjelaskan cara para cosplayer melakukan praktik politik identitas melalui event cosplay yang telah termediasi dalam channel Youtube. Selain itu, juga untuk mengetahui praktik crossdresser yang dilakukan oleh cosplayer dalam melihat event cosplay sebagai tempat bagi mereka saat mengenakan fashion yang tidak sesuai dengan gendernya, seperti cosplayer laki-laki bergaya dengan penampilan perempuan. Dalam pembahasan mengenai crossdresser ini, peneliti juga mengaitkan dengan postingan di instagram untuk memperkaya data terkait pengakuan yang ingin didapatkan oleh cosplayer melalui dunia virtual. 


\section{TINJAUAN PUSTAKA}

Dalam beberapa kasus, cosplay juga menjadi salah satu bentuk dari cara anak muda dalam mencari jati diri atau menemukan identitasnya (Rastati, 2012). Dengan cara menirukan gaya dan kostum dari karakter yang mereka tiru, hal itu menjadi salah satu bentuk dari cara mereka untuk mendalami identitas yang ingin ditunjukkan. Setiap cosplayer juga cenderung tidak hanya suka terhadap salah satu karakter. Namun, mereka juga melakukan cosplay terhadap karakter-karakter lain. Meski begitu pada akhirnya ketika mereka telah menemukan karakter yang paling tepat sebagai representasi dari diri mereka, maka karakter tersebut akan menjadi karakter yang paling dominan dibawakan oleh cosplayer ketika dalam event cosplay.

Penampilan identitas para cosplayer kini tidak hanya dapat dilihat melalui event, tetapi juga dapat dilihat melalui dunia virtual. Dunia virtual ini menjadi ruang yang dapat dimanfataatkan setiap individu atau kelompok untuk menampilkan identitas diri mereka. Turkle (Trisilowaty, 2017) menerangkan bahwa dunia virtual menawarkan suatu bentuk identitas yang dapat ditampilkan secara lebih bebas, cair, fleksibel, tidak terdesentralisasi, dan selalu dalam proses. Dengan demikian, melalui dunia virtual, apa yang mereka imajinasikan terhadap identitas yang ingin ditampilkannya dapat dituangkan dengan lebih mudah. Bahkan, mereka tidak dibatasi dengan cara mereka ingin menampilkan identitasnya itu.

Dunia virtual ini juga menjadi salah satu budaya populer yang juga disebut budaya layar dalam perspektif media baru. Dalam konteks ini budaya populer untuk menampilkan identitas para cosplayer di dunia virtual dapat dipahami sebagai berbagai suara, gambar, dan pesan yang diproduksi secara masal, salah satunya seperti di Youtube (Heryanto, 2018). Perkembangan teknologi dalam dunia virtual melalui Youtube ini memungkinkan semua kalangan, dalam hal ini para cosplayer dapat membentuk identitas mereka dengan mudah, melalui audio visual yang kemudian diunggah dalam channel mereka.

Event Cosplay dan Youtube selanjutnya dapat menjadi arena bagi para cosplayer untuk menampilkan diri dan identitasnya secara bebas, sebab para cosplayer juga menghadapi stereotype dari masyarakat tentang kehadirannya. Dalam pemberitaan di www.liputan6. com $^{1}$ pada rubrik lifestyle yang berjudul 6 Anggapan Keliru tentang Cosplayer dituliskan bahwa mereka memiliki stereotype yang negatif, di antaranya cosplay hanya untuk orang aneh, setiap cosplayer adalah eksibisionis, mereka adalah orang yang kesepian dan jomblo, cosplay hanya "mainan" anak muda, cosplay hanya menghabiskan uang, dan cosplayer dianggap orang yang tidak punya hobi lain.

Selain itu, stereotype negatif tentang para cosplayer juga diperbincangkan dalam forum daring Kaskus ${ }^{2}$, yaitu pada subforum The Lounge dengan judul Beberapa Alasan Orang Tidak Suka Cosplay. Dalam forum tersebut dibahas tentang cara para kaskuser memberikan

1 https://www.liputan6.com/lifestyle/read/2893134/6-anggapan-keliru-tentang-cosplayer. 2 https://www.kaskus.co.id/thread/52bf8e763ecb1768138b45ed/ beberapa-alasan-orang-tidaksuka-cosplay/ 
perspektifnya mengenai para cosplayer. Meski pada thread-nya dituliskan tentang perspektif negatif terhadap cosplayer, tapi dalam komentar yang muncul tidak hanya berupa judgment negatif terhadap mereka, tetapi juga terdapat penilaian-penilaian yang positif.

Berdasarkan anggapan yang telah tersebar di masyarakat itu membuat para cosplayer hanya dapat menunjukkan identitasnya ketika event berlangsung atau melalui dunia virtual. Apabila mereka menunjukkannya di tengah masyarakat tanpa ada event atau tempat yang menampung, maka mereka akan dipandang sebagai orang aneh. Oleh karena itu, pada saat tertentu mereka menjadi subaltern atau pihak yang terpinggirkan. Bahkan, ketika mereka bersosialisasi di tengah orang yang tidak menyukai cosplay, secara tidak langsung mereka akan dieksklusikan dan dapat dianggap sebagai othering karena berbeda dari lingkungan masyarakat yang dominan.

Selain itu, cosplay tidak hanya diikuti oleh para cosplayer yang menampilkan dirinya sesuai dengan gender dari diri mereka masing-masing. Di beberapa event cosplay yang telah terselenggara, seringkali juga dapat dilihat terdapat seorang laki-laki yang melakukan cosplay dengan menjadi karakter perempuan, sehingga identitas yang ditampilkan berlawanan dengan gendernya. Fenomena tersebut dalam dunia cosplay disebut crossdresser yang diartikan berpakaian lintas gender (Rastati, 2012). Fenomena tersebut dianggap pula sebagai bentuk perlawanan terhadap pakaian yang konvensional dan membenarkan segala kombinasi pakaian yang diinginkan guna menunjukkan identitas mereka.

Hal ini menunjukkan bahwa melalui cosplay, para cosplayer dapat menunjukkan identitas mereka secara cair sesuai dengan keinginan dan fantasi yang dimiliki. Hal ini selain menjadi bentuk dari hobi mereka ataupun cara mereka menunjukkan identitas, tapi juga dapat dilihat sebagai cara mereka dalam melawan kemapanan dalam hal berpakaian. Bentuk-bentuk pakaian yang digunakan dalam cosplay adalah pakaian yang tidak dipakai di tengah masyarakat pada umumnya. Bahkan, jika dikaitkan dengan fenomena crossdresser, hal itu semakin mempertajam bentuk perlawanan dari para cosplayer terhadap kemapanan pakaian yang ada di masyarakat. Ketika mereka berada dalam arena cosplay, baik dalam event ataupun melalui dunia virtual, para cosplayer memiliki kebebasan dalam menunjukkan identitas diri melalui pakaian atau kostum yang dikenakannya.

\section{METODE}

Metode yang digunakan peneliti dalam penelitian ini adalah deskriptif kualitatif. Peneliti memeriksa konten youtube yang di dalamnya berisi tentang video dokumentasi acara cosplay yang telah diselenggarakan. Berdasarkan video yang telah didapatkan, peneliti mengambil empat video dari Youtube dan salah satu akun instagram dari seorang cosplayer untuk dilakukan analisis terkait politik identitas yang dilakukan. Dalam analisis politik identitas ini, peneliti cenderung mengambil sampel capture video dan postingan yang mengarah pada isu gender.

Di samping itu, peneliti juga berfokus pada analisis dari fashion yang dikenakan oleh subjek dalam video dan postingan tersebut. Analisis fashion ini dilihat penting untuk 
dilakukan karena dalam politik identitas yang dilakukan oleh cosplayer, pilihan fashion yang dikenakannya memiliki peran yang penting guna mengomunikasikan identitas yang ingin ditampilkan. Dari fashion ini dapat dilihat cara seorang cosplayer berusaha menunjukkan eksistensi dirinya secara bebas tanpa terhalang oleh aturan yang berlaku di masyarakat, terutama persoalan yang memiliki keterkaitan dengan gender.

\section{HASIL DAN PEMBAHASAN}

\section{Fashion dalam Pembentukan Identitas Cosplayer}

Fashion sering dimaknai sebagai segala sesuatu yang dikenakan oleh seseorang, mulai dari pakaian hingga segala aksesoris yang menempel pada tubuhnya. Cara seseorang memilih fashion-nya seringkali digunakan untuk menunjukkan gaya hidup dan kelas dari diri mereka. Namun dalam kasus lain, pemilihan fashion juga identik untuk menunjukkan dan menegaskan identitas yang dimiliki seseorang. Salah satunya adalah fashion yang dipilih oleh cosplayer dalam merepresentasikan karakter anime, manga, hingga video games yang disukainya.

Apit (Rastati, 2012) menjelaskan bahwa para cosplayer yang cenderung berisi para anak muda dalam menggunakan kostum atau fashion dari karakter yang mereka inginkan, cenderung berusaha untuk menjungkirbalikkan peran gender tradisional, kode pakaian, kode fashion, nilai, dan perilaku. Hal ini menjelaskan bahwa fashion dalam cosplay menjadi bentuk perlawanan dari cara berpakaian yang telah mapan di masyarakat. Bentuk perlawanan dari fashion ini berupa pembenaran dalam mengombinasi pakaian atau kostum sesuai selera dari cosplayer yang memiliki kemungkinan berlawanan dengan kode etik berpakaian dari masyarakat umum. Melalui cara mengubah fashion dan peletakan berbagai ornamen sesuai keinginan cosplayer, maka dapat menciptakan identitas baru sesuai fantasi yang ada di benak mereka.

Membahas mengenai bentuk dari penjungkirbalikkan fashion gender tradisional, hal ini mengacu pada fenomena munculnya crossdresser dalam cosplay. Fashion gender tradisional yang dimaksud dalam hal ini adalah pemilihan fashion yang sesuai dengan gender yang berlaku di masyarakat, tentang bagaimana laki-laki harus berpakaian dan bagaimana perempuan harus berpakaian. Crossdresser muncul guna melakukan perlawanan terhadap hal tersebut, dimana para cosplayer ini sengaja memilih untuk berpenampilan layaknya perempuan sesuai karakter yang mereka sukai. Bagi mereka, bentuk fashion ini merupakan hal yang biasa dan mereka merasa puas dengan mengenakan pakaian tersebut.

Terdapat dua channel Youtube yang menampilkan hal tersebut ketika dalam event cosplay di Indonesia, yaitu channel milik Candra Salay dan Kimochi Channel. Dalam akun Candra Salay diperlihatkan cosplayer yang menggunakan fashion menyerupai karakter perempuan dan kemudian diwawancarai oleh pemilik akun tersebut. Dalam wawancara singkatnya tersebut, cosplayer ini tetap mengaku dirinya sebagai "mas" dan memilih fashion tersebut karena terpengaruh oleh temannya. 


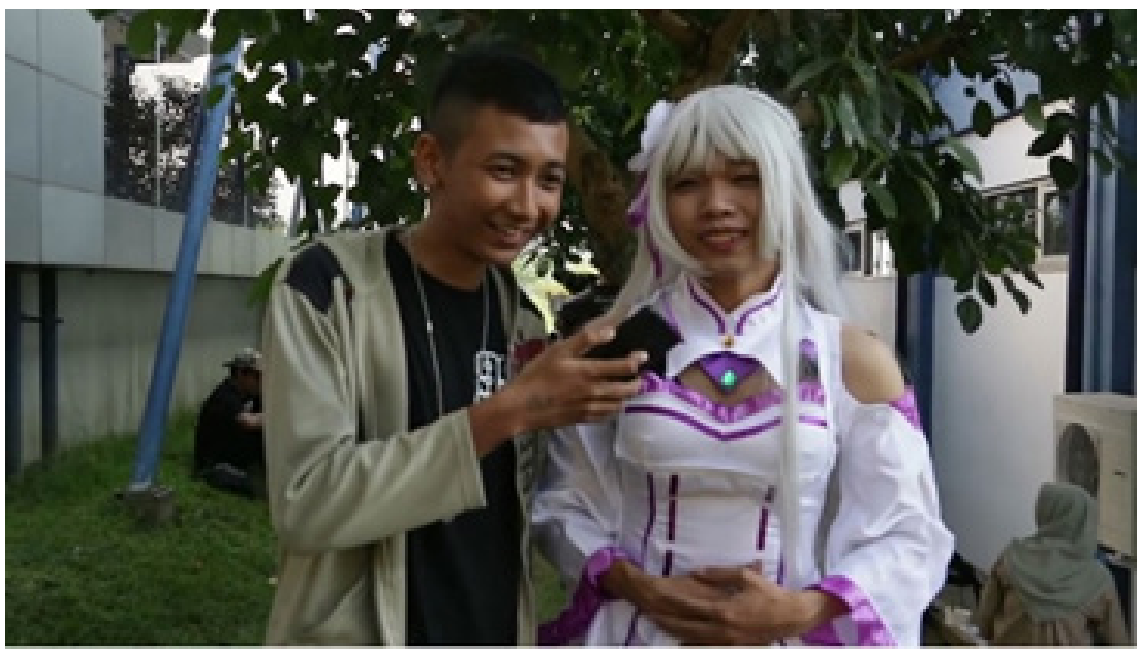

Gambar 1. Screenshoot tayangan Youtube Candra Salay Sumber: https://www.youtube.com/watch?v=x_rxHbWe-D4

Temuan dalam akun tersebut menunjukkan meskipun cosplayer yang telah melakukan crossdresser, namun jati dirinya tetap mengaku sebagai laki-laki dengan cara menjawabnya ketika ditanya oleh pemilik akun tersebut. Meskipun seorang cosplayer melakukan crossdresser, belum ada kemungkinan mereka benar-benar ingin menjadi seorang perempuan. Namun, dapat dikarenakan hanya karena ingin menampilkan karakter perempuan yang disukainya atau terpengaruh oleh lingkungannya. Dalam narasi yang dibawakan di akun tersebut, cosplayer itu menjawab bahwa dia melakukan crossdresser dikarenakan terpengaruh oleh temannya. Namun, hal ini tidak dapat menjadi satu alasan sebab jika dilihat dari penampilannya, mulai dari pemilihan pakaian, aksesoris, hingga wignya, penampilan dari crossdresser tersebut dapat dianggap totalitas sehingga meski dari jawabannya mengaku terpengaruh teman, tetapi dapat dilihat dari dirinya sendiri seakan ingin menunjukkan identitas melalui karakter cosplay perempuan tersebut secara totalitas.

Selanjutnya dalam akun milik Kimochi Channel juga melakukan vlog dalam event cosplay dan menjumpai cosplayer yang melakukan crossplay. Berbeda dengan akun Candra Salay, cosplayer dalam akun Kimochi Channel ini cenderung lebih jujur dan terbuka dalam memperlihatkan dirinya yang menikmati crossdresser yang dilakukannya. Hal tersebut diperlihatkan dari ekspresi yang ditunjukkan dalam video yang ditayangkan. Dalam video tersebut dia terlihat merasakan rasa senang dan puas saat menjawab pertanyaan seputar dirinya dan cosplay yang dilakukannya. Selain itu, dia juga merasa siap menjadi karakter perempuan yang lain ketika ditanya untuk menjadi karakter lain, asalkan kostumnya ada. 


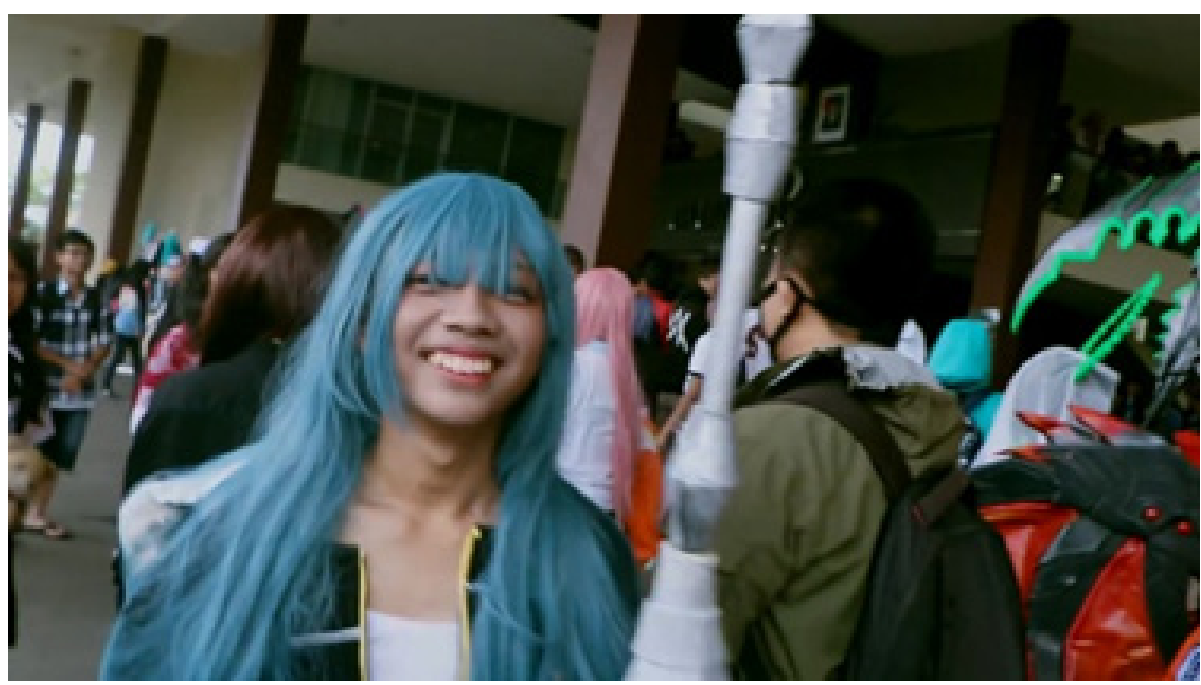

Gambar 2. Screenshoot tayangan Youtube Kimochi Channel Sumber: https://www.youtube.com/watch?v=4STOMeUVOyw

Berdasarkan temuan dari dua tayangan tersebut, dapat dilihat bahwa fashion crossdresser ini dapat dilihat sebagai cara mereka untuk melakukan konstruksi diri, yaitu untuk memperluas batasan fashion maskulin dan feminin (Rastati, 2012). Dengan melakukan crossdresser maka secara tidak langsung mereka melepas jeratan dari batasan fashion yang harus dikenakan baik oleh laki-laki maupun perempuan. Melalui hal tersebut mereka dapat memperoleh kebebasan dalam memilih dan mengenakan pakaian yang diinginkannya.

Meski bagi mereka, crossdresser dianggap sebuah bentuk kebebasan dalam memilih dan mengenakan kostum karakter sesuai dengan karakter yang mereka sukai. Namun, hal ini juga dapat memberikan stereotype baru terhadap identitas dirinya. Dengan memilih crossdresser, maka laki-laki dapat dianggap sebagai homoseksual serta laki-laki kemudian dapat dianggap negatif, sedangkan perempuan lebih superior (Rastati, 2012). Hal ini kemudian menjadi tantangan baru bagi para cosplayer, khususnya yang memilih fashion crossdresser, karena dapat memunculkan kemungkinan bahwa nantinya para pelaku crossdresser dapat menerima penilaian negatif dari lingkungan sekitarnya, meski apa yang mereka lakukan berada dalam panggung cosplay.

Di samping fashion crossdresser yang ditampilkan, channel Youtube di Indonesia masih lebih dominan menampilkan karakter cosplay yang straight, artinya karakter yang ditayangkan dalam channel Youtube ketika membuat konten di event cosplay adalah karakter yang sesuai dengan gender para cosplayer, salah satunya seperti yang ditayangkan pada channel milik Blast Wall Media yang ditunjukkan pada Gambar 3. 


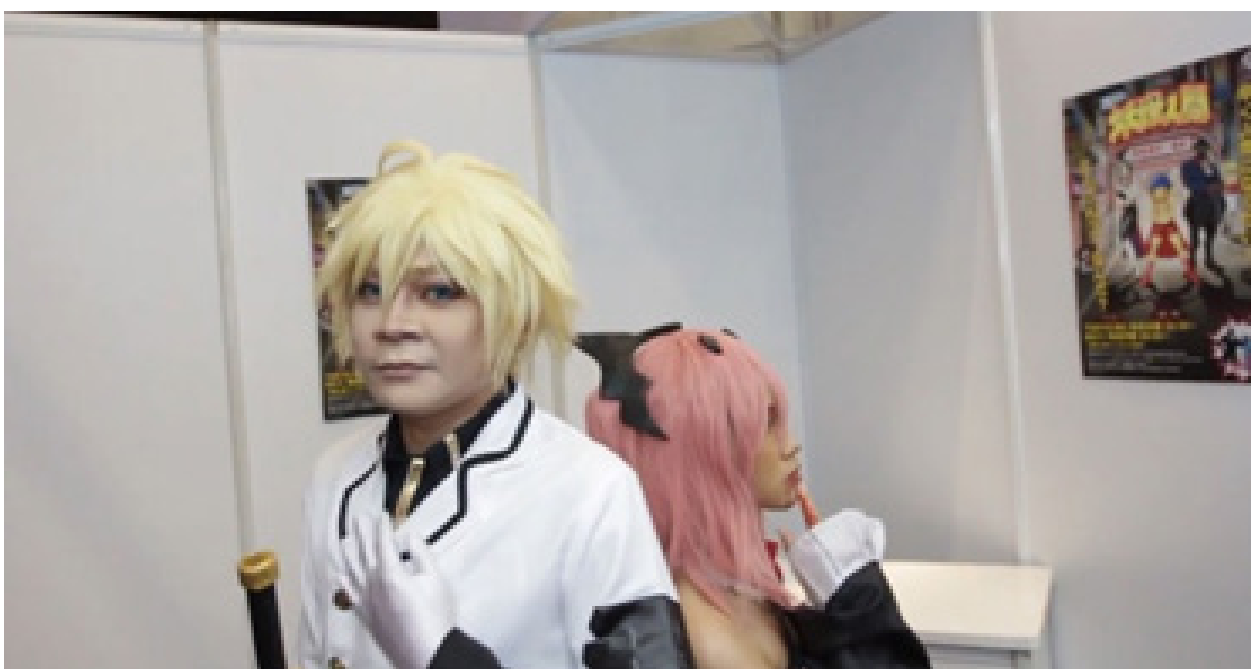

Gambar 3. Screenshoot tayangan youtube Blast Wall Media Sumber: https://www.youtube.com/watch?v=_y_2RfEETO8\&t=104s

Tren dalam berpakaian di Indonesia berkembang dengan keadaan lingkungan dan keadaan masyarakat yang ada di dalamnya, sehingga terdapat corak berpakaian yang membedakan antar daerah lain (Widanto \& Pratiwi, 2015). Di Indonesia sendiri pakaian pun diatur di masyarakat, misalnya cara berpakaian, aurat mana yang wajib ditutup, dan bagaimana kemudian sanksi yang akan diterima ketika terjadi pelanggaran terhadap cara berpakaian. Bahkan etika berpakaian di Indonesia ini kemudian turut mengatur media beroperasi dan menayangkan beberapa visual terkait dengan pakaian. Kemudian, dalam hal ini apabila dalam sebuah tayangan terdapat etika berpakaian yang melanggar, seperti menampakkan bagian aurat maka yang harus dilakukan oleh media, yaitu melakukan blur terhadap bagian tersebut.

Di Indonesia cara berpakaian telah diatur dalam sebuah norma dan etika. Setiap individu dalam berpakaian harus sesuai dengan ketentuan di masyarakat. Seperti seorang laki-laki sudah sewajarnya berpakaian dengan pakaian yang dikenakan laki-laki pada umumnya. Begitu juga perempuan yang memakai pakaian yang sewajarnya dipakai oleh perempuan. Ketika aturan ini dilanggar oleh individu, maka mereka akan berpotensi untuk memperoleh sanksi sosial.

Meski aturan di masyarakat, cara berpakaian yang dianggap sopan telah diatur sesuai etika yang berlaku, tetapi melalui cosplay nilai dan kode etik tersebut kemudian dilawan dan dileburkan. Melalui event cosplay, hal tersebut kemudian dapat dilawan. Para cosplayer dapat mengenakan fashion karakter sesuai yang mereka inginkan tanpa harus takut dengan kode etik yang berlaku di masyarakat. Banyak fashion yang kemudian dapat dilihat melawan kode etik yang berlaku di masyarakat. Namun, di sinilah letak perlawanannya, mereka dapat memakai kostum tersebut dengan leluasa tanpa takut adanya teguran. 


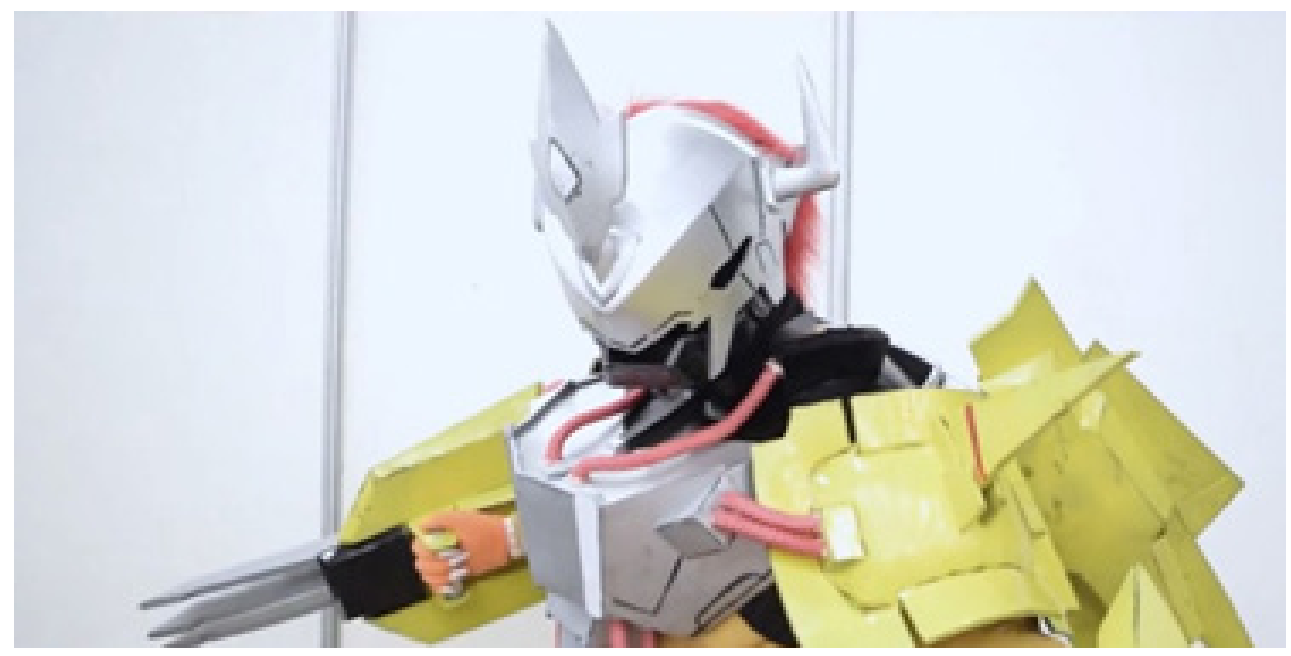

Gambar 4. Screenshoot tayangan youtube Coshouse Party Sumber: https://www.youtube.com/watch?v=jLbuTj5eJ7Y

Demi menunjukkan identitasnya, dalam pemilihan kostum para cosplayer tidak hanya berkutat pada fashion karakter perempuan ataupun laki-laki semata. Namun, di dalamnya mereka juga ada yang memilih untuk memilih karakter monster seperti pada Gambar 4. Melalui fashion dengan kostum yang dipilihnya ini, identitas yang ingin ditunjukkan bukan seputar sosok yang terlihat dari penampilan manusia saja. Namun cosplayer juga dapat menampilkan sosok yang ada dalam dirinya, mulai dari identitas keberanian, pahlawan, dan lain-lain. Dengan demikian fashion yang digunakan dalam berpakaian pada event cosplay ini pada akhirnya memiliki fungsi untuk menunjukkan identitas diri (Habibah, 2014).

Segala pemilihan fashion dalam mengikuti cosplay bagi seluruh cosplayer pada akhirnya memiliki alasan tersendiri terhadap identitas seperti apa yang mereka inginkan, baik itu pemilihan fashion crossdresser, straight, hingga monster. Seluruhnya merupakan bentuk dari cara cosplayer ingin merepresentasikan identitas mereka melalui fashion yang dipilihnya. Selain itu, fashion bagi para pelaku cosplay merupakan senjata paling dasar bagi mereka untuk melakukan politik identitas dalam rangka mendapatkan pengakuan (recognition) dari masyarakat terhadap keinginan mereka dalam memilih fashion, hobi, hingga dalam menunjukkan identitas mereka.

\section{Media sebagai Arena Politik Identitas Cosplayer}

Perkembangan teknologi yang kini sampai pada teknologi internet mendorong munculnya beragam media baru yang dapat dimanfaatkan untuk beragam kepentingan. Salah satunya adalah kepentingan dalam menampilkan identitas diri. Melalui media, setiap orang mampu menampilkan identitasnya secara bebas.

Bagi para cosplayer, hal ini dapat dimanfaatkan secara maksimal. Banyak platform yang dapat digunakan untuk menampilkan identitas diri melalui media, khususnya dalam ranah new media. Beberapa platform yang dapat dimanfaatkan untuk tujuan tersebut di 
antaranya melalui Facebook, Instagram, Youtube, dan lain-lain. Setiap platform media baru ini memiliki keunggulan masing-masing sesuai dengan karakter yang dimilikinya.

Pertama, melalui Facebook para cosplayer dapat membentuk identitas diri melalui akun yang mereka miliki. Dalam membentuk identitas ini, mereka tidak serta merta langsung membentuk identitasnya, tetapi mereka juga melalui tiga gambaran, yaitu orientasi personal, nilai-nilai individu, dan ekspresi diri (Ayun, 2015). Dalam gambaran orientasi personal, cosplayer menggunakan Facebook untuk berkomunikasi dengan orang lain. Dengan gambaran ini, melalui platform Facebook, hal ini dapat dilakukan dengan mencari pertemanan yang memiliki hobi yang sama ataupun masuk ke dalam grup yang di dalamnya merupakan para penggemar cosplay. Hal ini kemudian dapat menjadi sebuah ruang bagi mereka berekspresi tentang identitas diri mereka sebagai cosplayer. Bahkan, bisa menyerupai perkumpulan event cosplay tetapi dalam versi virtual.

Selanjutnya, nilai individu merupakan nilai personalitas yang dimiliki untuk menjaga kepercayaan diri seseorang dalam berkomunikasi. Dengan memiliki grup atau pertemanan yang memiliki kegemaran yang sama, maka nilai personalitas dapat dibangun. Ketika seorang cosplayer belum tentu dipandang sebagai suatu hal yang positif, pasti mereka menginginkan suatu hubungan pertemanan yang memiliki latar belakang mirip. Dengan memiliki pertemanan dengan orang yang sesama cosplayer, baik dalam grup maupun antar individu, maka dapat membantu mereka untuk membangun nilai personalitas. Hal ini penting menjadi bahan yang perlu diperhatikan karena nilai personalitas inilah yang kemudian dapat menentukan apakah cosplayer tersebut dapat bertahan menjadi bagian dari subkultur ini.

Kemudian pada gambaran ekspresi diri, melalui Facebook para cosplayer juga dapat menampilkan ekspresi dirinya, baik melalui penulisan status maupun melalui visual sesuai kebutuhan dari user-nya. Sebagai new media, Facebook memiliki fasilitas tersebut, sehingga melalui media ini, mereka tetap dapat menampilkan identitas mereka melalui bentuk ekspresi diri yang mereka inginkan.

Selanjutnya pada platform Instagram. Platform ini hampir memiliki kesamaan terhadap Facebook. Namun pada dasarnya kedua platform tersebut memiliki perbedaan. Instagram memungkinkan penggunanya untuk bersosialisasi dalam bentuk sharing gambar atau video melalui akun yang dimilikinya (Sakti \& Yulianto, 2016). Melalui fasilitas tersebut, para cosplayer dapat memanfaatkan Instagram untuk menunjukkan identitas mereka dengan tampilan visual. Sebab berbeda dengan Facebook yang mengedepankan teks berupa tulisan, Instagram sebagai platform new media lebih cenderung memberikan fasilitas berupa space yang lebih fokus dan utama dalam tampilan visual, seperti foto atau video. 


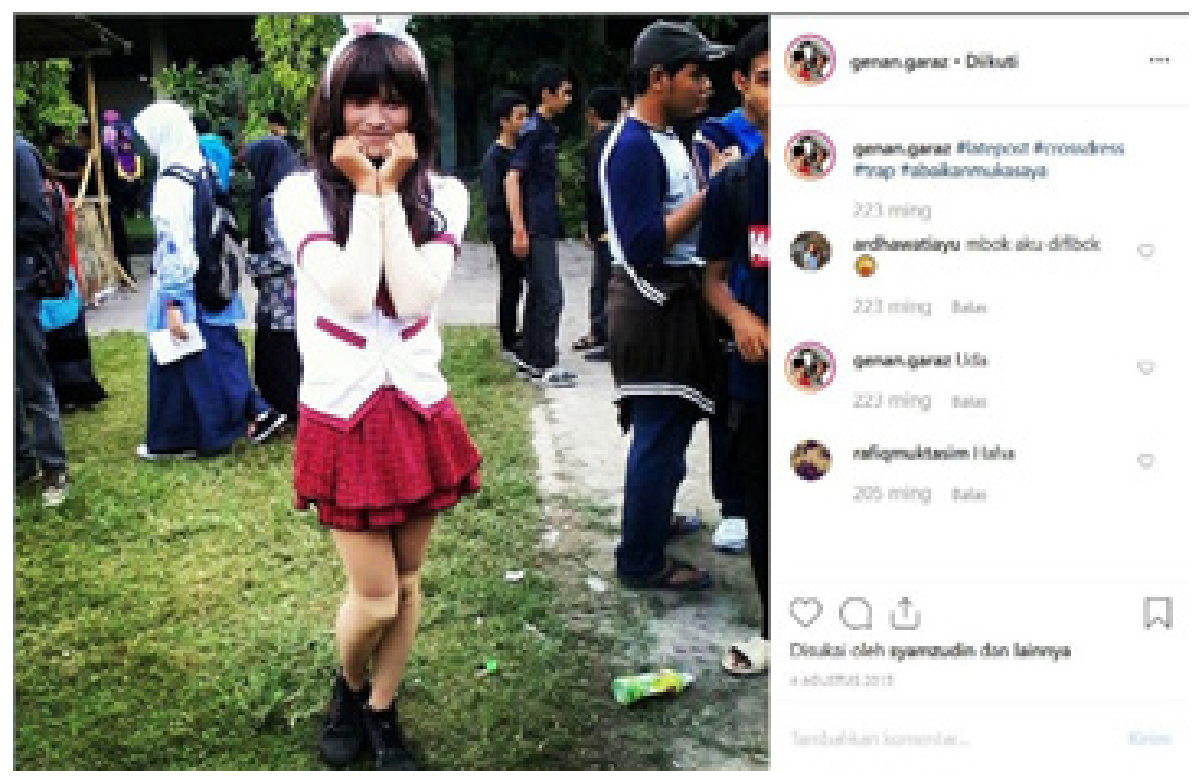

Gambar 5. Screenshoot cosplay crossdresser di instagram Sumber: https://www.instagram.com/genan.garaz/

Dari Gambar 5 dapat dilihat cara seorang cosplayer menampilkan identitas dirinya melalui Instagram. Dalam hal ini media dapat menjadi alat yang efektif guna mendukung keinginan cosplayer untuk eksis secara lebih luas di dunia virtual. Pada akhirnya media kemudian menjadi alternatif bagi para cosplayer untuk mendapatkan recognition dari apa yang mereka pilih.

Selanjutnya, media Youtube yang menjadi media paling kerap dikunjungi dan digunakan dalam mencari video. Identitas yang ditampilkan dalam bentuk video cenderung ditayangkan secara kompleks, artinya berbeda dengan pengguna Instagram ataupun Facebook yang menampilkan dirinya secara pribadi. Dalam Youtube, identitas yang ditampilkan cukup banyak yang diambil dari sebuah event cosplay, seperti yang dicontohkan pada subjudul sebelumnya. Meski begitu, Youtube juga dapat digunakan untuk menampilkan diri melalui eksplorasi yang artistik guna menunjukkan ekspresi diri mereka (O'Neil, 2014)

Selain itu, pada Youtube penayangan dari berbagai identitas cosplayer biasanya bukan dilakukan oleh para cosplayer yang menampilkan diri di lapangan. Namun hal tersebut ditampilkan oleh para content creator sehingga hal ini menunjukkan bahwa content creator menjadi kepanjangan tangan atau mediator dari Youtube untuk menampilkan identitas dirinya. Mereka ditampilkan sesuai dengan keinginan yang membuat konten sehingga dalam ranah media, hal ini tidak hanya dapat dilihat dalam ranah pembentukan identitas bagi para cosplayer, tetapi juga sebagai tempat melakukan komodifikasi para cosplayer bagi para pembuat konten.

Media sebagai arena politik identitas tidak hanya berkutat pada ketiga bentuk new 
media yang dijelaskan tersebut. Namun juga masih banyak terdapat beragam platform dan forum online yang juga menjadi tempat bagi para cosplayer melakukan politik identitas guna mendapatkan recognition secara luas, seperti melalui Twitter dengan kelebihan tagarnya untuk membuat viral segala sesuatu atau forum online kaskus yang mengandalkan thread sebagai induk informasi yang memungkinkan diskusi berjalan secara luas. Semua hal tersebut kini dapat termediasi oleh media, sehingga dalam membentuk sebuah identitas, para cosplayer dapat lebih luas dalam memilih media yang ingin digunakan sesuai dengan kehendak yang diinginkan.

\section{Politik Identitas Sebagai Bentuk Pencarian Recognition}

Membahas mengenai politik identitas dari para cosplayer tidak akan terlepas dari cara mereka membentuk identitas diri. Schau dan Gilly (dalam O'Neil, 2014) menjelaskan bahwa identitas diri merupakan komponen identitas seseorang yang dibentuk dengan sengaja dan nyata. Identitas diri merupakan hal yang sengaja dibentuk oleh individu untuk memperlihatkan bagaimana keinginan mereka dikenal dan bagaimana mereka ingin dilihat masyarakat. Identitas diri ini selanjutnya para cosplayer bentuk dengan cara menempelkan pakaian atau kostum yang mereka pilih dengan sengaja, sehingga hal tersebut terkesan nyata sebagai representasi dari diri mereka. Kesan tersebut juga mereka konstruksi melalui perilaku dan sikap yang ditiru dari karakter yang mereka cosplay-kan. Dengan demikian dalam pembentukan identitas diri ini, mereka tidak hanya menampilkan semata-mata melalui pakaian atau kostumnya tetapi mereka juga memperlihatkan bagaimana perilaku, sikap, dan gayanya juga menyerupai karakter yang ditiru. Hal inilah yang kemudian membuat identitas diri mereka terbentuk secara sengaja dan menjadi kenyataan, meski pada dasarnya apa yang mereka tunjukkan berawal dari fantasi yang dikonstruksikan menjadi sebuah serial manga, anime, atau video games.

Hal tersebut juga menunjukkan bahwa adanya politik identitas dengan menampilkan identitas diri secara sadar dan nyata juga tidak dapat terlepas dengan penggunaan tubuhnya. Mauss juga telah melakukan sebuah analisis terhadap penggunaan tubuh sebagai teknik representasi diri. Dia melihat bahwa berbagai cara dilakukan oleh manusia dengan menggunakan tubuhnya untuk melakukan komunikasi yang diinginkan guna menunjukkan identitas diri (O'Neil, 2014). Apa yang dilakukan dalam penggunaan tubuh untuk berkomunikasi sebagai bentuk politik identitas ini, menjadi sebuah tindakan sosial yang diperlukan. Tindakan semacam ini adalah bentuk dari keinginan mereka mendapatkan sebuah recognition. Kembali ke tujuan dari politik identitas, yaitu untuk mendapatkan recognition dari orang lain terhadap identitas diri yang ditunjukkan oleh seorang individu.

Bagi para cosplayer, mereka menampilkan diri dengan berbagai kostum yang beragam itu guna menunjukkan bagaimana tubuh mereka yang ditempeli berbagai pakaian atau kostum serta aksesoris menegaskan tentang identitas yang ingin mereka katakan terhadap publik. Schau dan Gilly menjelaskan bahwa dalam politik identitas ini, seseorang juga melakukan seni representasi diri yang merupakan manipulasi tanda-tanda dan representasi yang diwujudkan melalui pengalaman untuk memberikan sebuah identitas (O'Neil, 2014). 
Berkenaan dengan tanda-tanda ini, Bakker's mendefinisikan semiotik diri pada dasarnya adalah pandangan tentang diri dimana semiotika simbol yang menunjukkan kebiasaan dianggap hal yang serius (O'Neil, 2014). Wiley melalui karyanya The Semiotic Self juga menambahkan bahwa dalam semiotika diri ini terdapat dua nilai yang membentuk konsep identitas, yaitu operating values dan ideal values. Operating values adalah nilai yang beroperasi dalam perilaku sehari-hari dan dipraktikkan oleh orang atau kelompok sosial tertentu sedangkan ideal values adalah nilai yang diberikan seseorang atau kelompok sosial, tetapi belum tentu nilai tersebut dapat dipertahankan menjadi sebuah kenyataan.

Bagi para cosplayer, identitas diri yang mereka tampilkan tentu memiliki kemungkinan yang besar tidak dapat dilihat sebagai operating values. Hal ini dilihat bagaimana stereotype yang muncul terhadap para pelaku cosplay. Di samping itu ketika mereka menunjukkan identitas diri di tengah masyarakat dengan cara mengenakan kostum karakter cosplay-nya dalam kehidupan sehari-hari maka yang terjadi mereka akan dipandang sebagai orang yang aneh dan dapat dieksklusikan dari lingkungan sosialnya sehingga mereka hanya dapat menunjukkan itu ketika berada di panggung cosplay, atau melalui media yang mereka miliki. Dengan adanya mediasi tersebut, maka keberadaan mereka tidak akan dianggap aneh dan akan diakui.

Meski dalam kehidupan sosial keberadaan para cosplayer tidak dapat ditunjukkan setiap saat, tetapi media dapat menjadi mediasi untuk mereka agar tetap eksis di setiap waktu. Sebelumnya tanpa media, mereka hanya mampu menunjukkan identitas dirinya hanya ketika melalui event cosplay. Ketika mereka menunjukkan di lingkungan pertemanan atau sosialnya maka akan muncul kemungkinan mereka menjadi bahan perundungan. Namun, dengan adanya arena cosplay maka mereka dapat mengekspresikan identitasnya secara bebas tanpa harus takut dengan ancaman tersebut.

Selanjutnya, media kini memberikan peluang bagi para cosplayer untuk melakukan politik identitas dengan menampilkan identitas diri mereka melalui social media yang mereka miliki, seperti yang telah dijelaskan dalam subjudul sebelumnya. Dengan adanya media daring, mereka selanjutnya dapat setiap saat melakukan konstruksi identitasnya melalui social media-nya. Hal ini kemudian menjadi bentuk dari perlawanan terhadap operating values yang tidak didapatkan oleh para cosplayer di dunia nyata karena adanya hambatan terhadap stereotype yang ditempelkan kepada mereka dan anggapan mereka aneh. Namun media membuat hal tersebut tidak muncul. Melalui media daring, mereka tidak lagi dianggap aneh meskipun menampilkan identitas diri sebagai cosplayer tersebut sebab melalui dunia virtual mereka memiliki kebebasan untuk tampil seperti apa. Bahkan, dengan kemunculan social media dapat ditemukan beragam identitas diri yang ditampilkan dan meskipun identitas diri tersebut tidak biasa di tengah masyarakat, mereka berhasil mendapatkan banyak recognition. Recognition ini dapat dilihat dari berbagai balasan di postingan yang mereka unggah di medianya masing-masing. Bahkan, dari cara mereka menunjukkan hal tersebut, ada pula yang sampai menjadi terkenal berdasarkan pantauan dari jumlah followers atau pertemanan yang mereka miliki di akun social media-nya. 
Selanjutnya, pada ideal values, hal ini mereka dapat dari penilaian seseorang, berbeda dengan operating values yang berlaku di tatanan hidup sosial. Jika berbicara tentang operating values tadi, recognition di dunia virtual dapat mereka peroleh dari orangorang yang memiliki kesamaan dalam menyukai bidang tersebut sehingga operating values dapat berjalan dengan lancar di dunia virtual. Namun berbeda dengan ideal values, karena nilai ini belum tentu dapat dipertahankan dalam kehidupan sosial.

Ideal values ini dapat diperoleh ketika orang-orang yang bukan dari golongan pecinta cosplay mengakui identitas cosplayer tersebut. Akan tetapi, pengakuan tersebut bersifat sementara karena terbatas pada aturan sosial yang dominan. Misalnya ketika seorang yang awam terhadap cosplay, mereka mendatangi event tersebut dan kemudian menyukainya, hal itu hanya akan bertahan ketika dia berada di event tersebut. Kemudian setelah dia keluar dari event itu, maka penilaian positif itu akan menjadi pudar kembali karena terhalang oleh nilai sosial yang berlaku dominan di masyarakat. Hal ini juga berlaku ketika orang lain melihat identitas cosplay di social media. Mereka akan menilai hal itu bagus ketika identitas yang ditampilkannya sempurna sesuai dengan karakter yang ditirunya, tetapi pada akhirnya hal itu juga akan hilang ketika mereka keluar dari social media.

Dalam melakukan politik identitas untuk memperoleh recognition dari pihak lain, semuanya tidak dapat terlepas dari bagaimana cosplayer berusaha menampilkan identitas dirinya. Untuk menampilkan identitas dirinya tersebut, cosplayer tidak dapat melepaskan diri dari politik tubuh. Sebab identitas diri yang dilihat orang lain pertama kali adalah melalui apa yang menempel pada tubuh mereka. Pakaian dan aksesoris apa yang mereka kenakan dapat memberikan persepsi awal mengenai identitas diri mereka sebagai apa. Hal ini kemudian tidak terlepas dari adanya simbol-simbol yang tertempel pada diri cosplayer. Selanjutnya dari hal inilah muncul beragam penilaian terhadap identitas para cosplayer, yang dapat dilihat dari operation values dan ideal values, yaitu bagaimana nilai beroperasi pada kehidupan sosial dan masyarakat dan bagaimana mereka menempelkan nilai tersebut terhadap objek identitas yang mereka lihat. Semua itu memengaruhi keberadaan dan seberapa jauh para cosplayer memperoleh pengakuan di dalam masyarakat.

\section{SIMPULAN}

Politik identitas bagi para cosplayer dilakukan untuk memperoleh recognition. Hal ini dikarenakan sebagai budaya populer yang berasal dari Jepang dan masuk ke Indonesia, para cosplayer juga menerima berbagai stereotype yang negatif. Hal ini membuat mereka secara tidak langsung menjadi pihak yang termarjinalkan karena hadirnya stereotype tersebut di lingkungan sosial mereka sehingga membuat kehadiran mereka sangat terbatas dalam suatu arena.

Kehadiran teknologi pada akhirnya dapat menjadi salah satu jalan bagi mereka untuk mencari recognition. Awalnya mereka hanya dapat menampilkan identitas diri mereka ketika ada event cosplay. Namun, dengan adanya teknologi internet yang melahirkan dunia virtual dengan dimediasi oleh beragam platform, hal tersebut mulai teratasi. Kemudian, 
media dapat dilihat menjadi alat bagi mereka untuk mendapatkan recognition. Bentukbentuk recognition ini dapat dilihat dari beragam hal, di antaranya jumlah follower dan pertemanan dalam akun media sosial yang mereka miliki.

Selain itu dalam hal identitas, mereka menunjukkan identitas diri dapat dilihat dari pemilihan fashion karakter, baik anime, manga, maupun video games. Pemilihan karakter tersebut menunjukkan seperti apa identitas yang cenderung mereka ingin tampilkan. Tidak hanya identitas berupa gender yang straight, tetapi mereka juga memunculkan identitas yang berlawanan, seperti dengan memilih crossdresser hingga kostum monster. Hal itu menjadi bentuk perlawanan dari kemapanan mereka atas pakaian pada umumnya yang diyakini dalam masyarakat.

Terkait dengan fashion crossdresser, dapat dilihat bahwa event cosplay dapat menjadi tempat bagi mereka untuk mewujudkan hal tersebut. Ketika mereka berada di tengah masyarakat, maka mereka mau tidak mau harus terikat dengan aturan yang berlaku agar tidak dikenai sanksi sosial. Akan tetapi, ketika mereka berada di event cosplay seperti yang ada dalam tayangan Youtube tersebut, mereka dapat secara bebas mengekspresikan identitas dirinya yang ingin ditampilkan. Event cosplay membantu mereka untuk memperoleh panggung tersebut. Selanjutnya, media seperti Youtube ataupun Instagram semakin memberikan ruang bagi mereka untuk lebih menunjukkan eksistensi dirinya guna mencapai recognition yang diharapkan.

Berdasarkan hal yang telah dijelaskan ini, cosplay tidak hanya sekadar menirukan karakter yang ada pada suatu anime, manga, atau video games tetapi juga menjadi sebuah praktik perlawanan dan bentuk konstruksi dari identitas diri. Hal ini juga merujuk pada praktik politik identitas yang dilakukan oleh para cosplayer dengan tujuan memperoleh recognition dari pihak atau masyarakat dalam lingkungan sosialnya. Dengan begitu ruang ekspresi yang mereka inginkan untuk tampil dapat terbentuk. Baik di event cosplay maupun di ruang virtual seperti Youtube dan Instagram, keduanya memiliki peran penting bagi mereka untuk dapat eksis di tengah masyarakat.

\section{DAFTAR RUJUKAN}

Ardhani, S. A., Wulan, R. R., \& Malau, R. M. (2017). Identitas Diri Pelaku Cosplay (Studi Fenomenologi Cosplayer di Komunitas Cosplay Bandung). e-Proceeding of Management (hal. 3281-3294). Bandung: Telkom University.

Ayun, P. Q. (2015, Desember). Fenomena Remaja Menggunakan Media Sosial dalam Membentuk Identitas Diri. Channel, 3(2), 1--6.

Channel, K. (2017, Oktober 30). https://www.youtube.com/watch?v=4STOMeUVOyw. Diambil kembalidariwww.youtube.com:https://www.youtube.com/watch?v=4STOMeUV0yw

genan.garaz. (2015, Agustus 4). https://www.instagram.com/genan.garaz/. Diambil kembali dari https://www.instagram.com/: https://www.instagram.com/genan.garaz/

Habibah, S. (2014). Sopan Santun Berpakaian dalam Islam. Jurnal Pesona Dasar, 2(3), 65-78. 
Heryanto, A. (2018). Identitas dan Kenikmatan Politik Budaya Layar Indonesia. Jakarta: Kepustakaan Populer Gramedia.

Media, B. W. (2018, September 3). https://www.youtube.com/watch?v=_y_2RfEETO8\&t=104s. Diambil kembali dari https://www.youtube.com/: https://www.youtube.com/ watch?v=_y_2RfEETO8\&t $=104 \mathrm{~s}$

O'Neil, M. G. (2014). Transgender Youth and Youtube Videos: Self-Representation and Five Identifable Trans Youth Narratives. Dalam M. G. O'Neil, \& C. Pullen (Penyunt.), Queer Youth And Media Cultures (hal. 34-45). United States, United Kingdom: PALGRAVE MACMILLAN.

Party, C. (2018, September 10). https://www.youtube.com/watch? $v=j L b u T j 5 e J 7 Y$. Diambil kembali dari https://www.youtube.com/: https://www.youtube.com/ watch?v=jLbuTj5eJ7Y

Rastati, R. (2012, Oktober). Media dan Identitas: Cultural Imperialism Jepang Melalui Cosplay (Studi terhadap Cosplayer yang Melakukan Crossdress). Jurnal Komunikasi Indonesia, 2(1), 41-52.

Sakti, B. C., \& Yulianto, M. (2016). Penggunaan Media Sosial instagram dalam Pembentukan Identitas Diri Remaja. Interaksi Online, 6(4), 1-12.

salay, c. (2018, Mei 9). https://www.youtube.com/watch?v=x_rxHbWe-D4. Diambil kembali dari https://www.youtube.com/: https://www.youtube.com/watch?v=x_rxHbWe-D4

Trisilowaty, D. (2017). Eksistensi dan Identitas di Media Baru. Komunikasi, XI(01), 86-92.

Widanto, F. R., \& Pratiwi, F. D. (2015). Audience Adaptation dalam Gaya Berpakaian (Studi Deskriptif Kualitatif Trend Jilboobs pada Mahasiswi Yogyakarta). Jurnal Komunikasi Profetik, 08(02), 81-93.

www.kaskus.co.id. (2013, Desember 29). https://www.kaskus.co.id/ thread/52bf8e763ecb1768138b45ed/beberapa-alasan-orang-tidak-sukacosplay/. Diambil kembali dari www.kaskus.co.id: https://www.kaskus.co.id/ thread/52bf8e763ecb1768138b45ed/beberapa-alasan-orang-tidak-suka-cosplay/

www.liputan6.com. (2017, Maret 23). https://www.liputan6.com/lifestyle/read/2893134/6anggapan-keliru-tentang-cosplayer. Diambil kembali dari www.liputan6.com: https://www.liputan6.com/lifestyle/read/2893134/6-anggapan-keliru-tentangcosplayer 